\section{Footing the bill}

\section{Gout: The Patrician Malady}

by Roy Porter and G. S. Rousseau

Yale University Press: 1998. 393 pp. \$35, £25

\section{Anne Crowther}

Gout is a great subject for showing how the perception of illness is determined by social preoccupations. Most recently, the public's preoccupation with AIDS as a 'gay plague' reduced awareness of other types of transmission, just as in the past there were stereotypes of the 'consumptive' personality. Gout, although it is a widespread malady which causes great pain and can only be relieved, not cured, is still associated with a social profile developed most vigorously during the eighteenth century. It is an ailment chiefly associated with older males, and, by longstanding convention, with the rich.

Although Roy Porter and G. S. Rousseau note the current expansion of gout to countries where it was once little known, as a 'disease of civilization', they are less concerned with its modern position than its cultural heritage. Their book therefore mainly examines the work of medical theorists and the often detailed introspections of patients. Gout has a tremendous cast of characters: on the arts side there are Samuel Johnson, William Cowper, Edward Gibbon, Horace Walpole, Tobias Smollett and many more. On the science side are Francis Bacon and William Harvey (possibly), Thomas Sydenham, Benjamin Franklin and generations of Darwins.

The Greeks had been concerned about gout, though they did not distinguish it from arthritic problems. 'Podagra' was a suitably vague description, placing gout in its usual location, the foot, but the ailment was also suspected of mounting internal attacks, sometimes described as 'flying' or 'wandering' gout. The Greeks saw gout, like many other diseases, as due to an internal imbalance in the body, although the question of external influences was often raised.

Sydenham's Treatise on the Gout (1683), set the seal on gout's long-term definition as a disease of the wealthier classes. He also placed it as an imbalance of the constitution rather than an infectious or externally conditioned disease, holding that gout was related to luxurious living and overindulgence in alcohol. The logic of this type of analysis was that the body reacted to the morbid humours within itself by banishing them to the extremities, where they could do relatively little harm. Gout was not a fatal malady; indeed, it was believed to be a sign that the body was insulating itself against more serious illness. Nervous and sensitive temperaments, as many creative patients agreed, were likely to be most susceptible. They could also use their malady as an

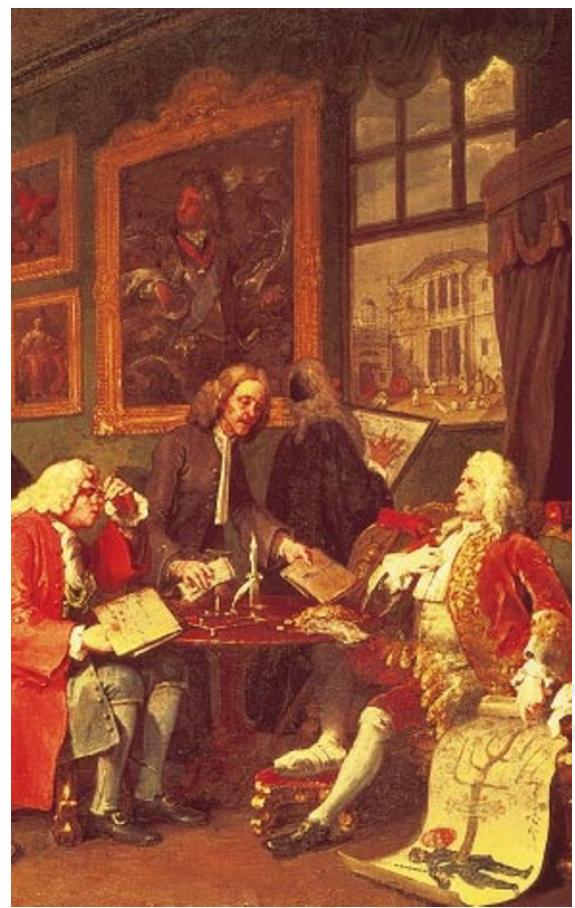

Rich man's illness: gout has long been associated with the leisured classes, as seen here by Hogarth.

excuse for retreating into their sedentary work.

In 1771, William Cadogan's influential book on gout claimed that it was preventable and not hereditary, and that its predisposing causes were "excess and idleness". Porter and Rousseau show that the current language of gout reflected the political theories of the day; the same language was applied to disorders of the body and the body politic. The higher-class theorists offered impeccably logical explanations but not much hope of a cure. Sydenham recommended opium and digestives, Cadogan concentrated on regimen. But this did not prevent gout from becoming a lucrative field for the medical profession. The whole medical armoury was tried at one time or another: heat, cold, bleeding, cupping, purgatives, and more exotic personal remedies such as boiled horse dung and oil extracted from human bones. There were also many secret remedies. Some of these included colchicum (often called autumn crocus), which is effective in relieving gout. George IV demanded it in place of the violent remedies suggested by his physicians.

Although this is a very cheerful book 'ludic', to use a favourite word of the authors — it also has some of the problems common to most works that try to hammer out signs and signifiers over the centuries through the examination of stray references. This is most apparent in the chapters on the nineteenth century, where the literary manifestations are considerably less interesting than those of the eighteenth. Gout still appeared as a rich man's malady and hence a convenient shorthand for the dissipated habits of the ruling classes, but writers who endured the condition were much more reticent, leading Porter and Rousseau into much discussion of "suppressed" gout. The gouty Wilkie Collins afflicted the enervated squires in his novels with a gout-like, but nameless malady. Joseph Conrad, another martyr to gout, never mentioned it in his fiction. Neither Jane Austen nor Thackeray afflicted their upper classes with gout. Eliot's baronets are also in prime condition, and lazy mentally rather than physically. Gout was losing its imaginative hold. But gout remained a refuge for the writer, and an excuse for retreat from the world. This was particularly obvious in Coleridge and Tennyson, but also in Darwin, who named gout as one of the many ailments that allowed him to avoid society and concentrate on his books.

Sometimes the line of argument on suppressed gout, fascinating though it is, fails to convince. Admirers of George Eliot's Middlemarch will not recognize Porter and Rousseau's imaginative interpretation. They will not think of the small town of Middlemarch as antithetical to the surrounding country, but of the "movement and mixture" between them that Eliot describes; they will expect to find Lydgate the nephew, not the son, of a baronet (indeed, in Gout he appears as both son and nephew in the same paragraph); they will be irritated by the references to "Ros", since Rosamund was never so abbreviated by her creator; they will think that the solitary comment on gout as a disease with "a good deal of wealth on its side" appears at the end of the book, not at the beginning; they will believe that $\mathrm{Mr}$ Casaubon was called Edward, not Isaac; that Lydgate does not retreat from medical practice to write on gout, but uses the reputation he has gained from his treatise on the subject to attract wealthy patients; and that he does not die of a possible "suppression" of gout, but of diphtheria. Perhaps the authors have not been using the standard 1874 edition, but it will be hard to convince Eliot's admirers that gout is a culminating symbol of this mighty work.

Scientific sources for the nineteenth-century, however, are more plentiful, and the scientific discussion is straightforward and absorbing. In mid-century, Alfred Baring Garrod showed how to detect uric acid in the blood, and linked it clearly with gout. Garrod was also firm on the role of alcohol. But, as the authors show, his work did not stifle the debate on how far hereditary factors were involved, nor on whether gout was treatable.

The last two chapters are not chronological but discursive, analysing the language of gout in terms of contemporary political and social perceptions and through the visual heritage. The excellent illustrations are concentrated on the eighteenth century, and reflect the comic, aristocratic and self-indulgent themes of the narrative. There is only 
one twentieth-century cartoon, more meaningful in the American context, again suggesting that gout is a financial boon to the medical profession.

Susan Sontag argued, at the height of the AIDS panic, that illness should be seen as a scientific category, not a cultural or moral stigma. In their brief epilogue, Porter and Rousseau argue the contrary, that social metaphors may enable the patient to cope with disease. The pain of gout was bearable because of its excellent pedigree and its apparent promise of insulation from worse maladies. Yet the book also shows how regularly, and erroneously, medical men believed that they had understood this elusive complaint. Underneath its fashionable phraseology, which the reader will appreciate according to taste, this entertaining book succeeds very well as an old-fashioned treatise on medical hubris.

Anne Crowther is in the Department of Economic and Social History, University of Glasgow, Glasgow G12 8QQ, UK.

\section{Liberator or 'fix'?}

\section{On the Pill: A Social History of Oral Contraceptives 1950-1970}

by Elizabeth Siegel Watkins

Johns Hopkins University Press: 1998. 202 pp.

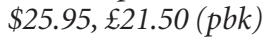

\section{Richard Davenport-Hines}

In 1960, the US Food and Drug Administration accepted the G. D. Searle pharmaceutical company's Enovid pill as an oral contraceptive. By the thirtieth anniversary of this event, 80 per cent of US women born since 1945 had used contraceptive pills at some time in their lives. The pill had been swallowed as a daily routine by more humans than any other prescribed medicine. The US Ladies' Home Journal declared on this anniversary that the pill had "transformed our lives" even more than "winning the right to vote", while The Economist included the pill as one of the seven wonders of the modern world.

Elizabeth Siegel Watkins set herself the tasks of testing these claims in her intelligent and well-structured monograph, and of documenting changing perceptions of oral contraception from a "private vice" to a "public virtue" and finally to an issue of individual discretion. There is one drawback to her approach. Her evaluation is exclusively concerned, by her own admission, with "the impact of the pill on middle-class American society". In confining her researches to the United States, and by focusing on the experiences and practices of that nation's more articulate citizens, her work can seem insular. Bernard Asbell's The Pill: A Biography of the Drug That Changed the World (Random House, 1995) is more journalistic, but his careful placing of US experiences in an international context provides a more suggestive treatment of social policy issues than Watkins.

In 1951, the feminist American philanthropists Margaret Sanger and Katherine McCormick commissioned the scientist Gregory Pincus to develop an infallible oral contraceptive, intended to liberate women's sexual acts from anxieties about their fertility. This stimulated other researchers to enter the field. In 1957, the G. D. Searle pharmaceutical company began marketing Enovid, ostensibly to treat gynaecological disorders. Its anovulant and therefore contraceptive properties became so well known, however, that by 1959 half a million US women were using it.

Contrary to widespread public and professional beliefs, the contraceptive revolution of the 1960s did not cause a sexual revolution. As demographers analysed the contraceptive habits of married women to document the contraceptive revolution (the pill was unavailable to unmarried women in many areas until the early 1970s), sociologists surveyed the sexual practices of unmarried women to depict long-term changes in sexual behaviour, and journalists bastardized their findings to present their caricature of 'the swinging sixties'. Yet years before Enovid, Alfred Kinsey and other sexual researchers had reported rates of pre-marital sexual intercourse steadily rising since the late nineteenth century. During the 1950s, the US marriage rate reached an alltime high, and the average age at which people married reached its all-time low; by 1959 almost half of brides were aged 18 or less. Many did not want to be burdened immediately with children, but reliable contraceptive information and technology was often unavailable. American puritanism flourished then as now. In 1960, 30 states of the union retained statutes prohibiting or restricting the sale or advertisement of contraceptives. Only in 1972 did the Supreme Court declare unconstitutional a Massachusetts law prohibiting the sale of contraceptives to unmarried people.

Watkins summarizes medical controversies surrounding the pill's safety. From the 1960s, medical studies linked the pill with an increased risk of strokes and breast cancer (although other studies reported that oral contraceptives protected against uterine and ovarian cancers). The validity of these findings has never been conclusively settled. Indeed, during the 1970s, the subject was confused by an often sensationalist 'media blitz', and mired by the intervention of individuals who objected to 'planned parenthood' on religious grounds, or to sexually independent women for other reasons. As a result of these 'health scares', by 1988 almost half of US married couples relied on either male or female sterilization to avoid preg- nancy. American physicians' fear of malpractice suits raised important issues of 'informed consent' when prescribing oral contraceptives.

Some American feminists also turned against the pill in the 1970s. They regarded it as a technological 'fix' which did not address fundamental issues of oppression. Resenting any form of birth control kept within the jurisdiction of the medical profession, they advocated the diaphragm and cervical cap as barrier contraceptives that women could personally administer. The identification in the 1980s of the sexual transmission of HIV led to a revival in the popularity of condoms. In the early 1990s, Norplant, a subdermal implant that releases a synthetic hormone into the blood, and Depo-Provera, a hormone injection with contraceptive effect, have become available in the United States. However, further contraceptive innovations are unlikely to be developed in the United States. All but one of its pharmaceutical companies were scared out of contraceptive research and development in the 1980s by the intolerable litigiousness of American society.

On the Pill, which contains splendid illustrations, is, within its declared limits, an admirable exercise in social history. It depicts the cultural and ideological pressures on US medicine while demonstrating why about 19 million American women still use the pill in 1998.

Richard Davenport-Hines is at 51 Elsham Road, London W14 8HD, UK.

\section{Even a loose cannon may hit the right spot}

\section{Dancing Naked in the Mind Field}

by Kary Mullis

Pantheon: 1998. 222 pp. \$24

\section{DanielS. Greenberg}

In addition to scientific immortality and a wad of cash, the Nobel Prize provides an irrevocable licence to pontificate publicly on any topic, relevant or not to the recipient's expertise. Winners at other great competitions, for example, the Academy Awards and the Miss America contest, may assume an unrestricted right to mount the soap box and pronounce on issues of the day. But, for drawing a respectful, guaranteed audience, no honour can match the Nobel Prize. And no Nobel laureate comes close to Kary Mullis in the exercise of the accompanying pontifical rights.

Mullis earned a place in scientific history in 1983 as the inventor of the polymerase chain reaction (PCR), which quickly became the indispensable laboratory technique for genetics research. For this achievement, he shared the 1993 Nobel Prize for 